\title{
Article \\ Online Buyers and Open Innovation: Security, Experience, and Satisfaction
}

\author{
Luis Enrique Valdez-Juárez ${ }^{1, *} \mathbb{B}$, Dolores Gallardo-Vázquez ${ }^{2} \mathbb{C}$ and Elva Alicia Ramos-Escobar ${ }^{1}$ \\ 1 Department of Business and Economics Sciences, Technological Institute of Sonora Mexico, \\ Obregon City 85000, Mexico; elba.ramos@itson.edu.mx \\ 2 Department of Financial Economics and Accounting, Faculty of Economics and Business, \\ University of Extremadura, 06006 Badajoz, Spain; dgallard@unex.es \\ * Correspondence: levaldez@itson.edu.mx; Tel.: +52-622-103-0253
}

Citation: Valdez-Juárez, L.E.; Gallardo-Vázquez, D.; Ramos-Escobar, E.A. Online Buyers and Open Innovation: Security, Experience, and Satisfaction. J. Open Innov. Technol. Mark. Complex. 2021, 7, 37. https://doi.org/10.3390/ joitmc7010037

Received: 31 December 2020

Accepted: 15 January 2021

Published: 18 January 2021

Publisher's Note: MDPI stays neutral with regard to jurisdictional claims in published maps and institutional affiliations.

Copyright: (c) 2021 by the authors. Licensee MDPI, Basel, Switzerland. This article is an open access article distributed under the terms and conditions of the Creative Commons Attribution (CC BY) license (https:// creativecommons.org/licenses/by/ $4.0 /)$.

\begin{abstract}
The topic of consumer behavior in a social context is important due to its influence on the behaviors and attitudes of individuals. New online business models are adopting open innovation practices focused on improving their sales channels through their technological capacity. In this paper, we analyze the purchase intentions in a business context to identify consumer needs through the proper purchase decision process. We must also observe the internal and external factors that influence consumer behavior. More exactly, electronic commerce is facing challenges and opportunities manifested by online consumers, such as design, security, trust, risk, uncertainty, and satisfaction with online purchases. Many external factors (economic, political, social, environmental, and health) influence buyers' intentions and behaviors. The objectives of this study are to (1) determine the influence of the security level of websites on purchasing behaviors (socially responsible and panic buyers), (2) determine the effect of website security on consumer satisfaction, (3) determine the effect of buyers (socially responsible and panic buyers) on the level of satisfaction, and (4) examine if the buyer experience has a moderating effect between the variables (socially responsible and panic buyers) and the dependent variable (customer satisfaction). We focus on a sample of 663 socially responsible online buyers and panic buyers from the Sonora, Baja California, and Sinaloa regions in Mexico. Data were collected from the months of April to August 2020, and an online questionnaire was used address to each of the residents of these regions aged between 20 and 55 and who were economically active. The data were analyzed using the structural equation model-partial least squares (SEM-PLS) model based on variance. The findings show that website security has significant positive effects on socially responsible buyers, panic buyers, and the level of customer satisfaction. Socially responsible buyers also have positive effects on customer satisfaction. However, the relationship between panic buyers and customer satisfaction is not supported. Related to a moderation analysis, that the buyer experience has a significant effect on the relationship between socially responsible online buyers and the level of satisfaction. Conversely, we find empirical evidence of the buyer experience having no significant effect between panic buyers and customer satisfaction. Our findings contribute to the development of various theories: the theory of behavioral reasoning (BRT), social identity theory (SIT), and the technological adaptation model (TAM). From an academic point of view, the findings are positive and encouraging, contributing to the literature on the e-commerce, behaviors, and attitudes of purchase intentions of individuals. Our work is incorporated into the existing literature on purchase intention and virtual business models, whose characteristics need to continue to be outlined, constituting a popular business model in recent years.
\end{abstract}

Keywords: open innovation; website security; socially responsible buyer; panic buyer; customer satisfaction

\section{Introduction}

Over time, consumer behavior has been studied within a psychological context and in the area of business sciences due to the complexity of its analysis and measurement $[1,2]$. 
From the social context, psychology is the discipline that has focused the most on analyzing the behaviors and attitudes of individuals regarding purchase intentions [3]. The theory of reasoned action (TRA) and social identity theory (SIT) are among the most used and studied in this context [4,5]. However, business science, through marketing, has recently been focusing on discovering consumer needs and behaviors through the purchase decision process [6]. This last discipline is based on behavioral reasoning theory (BRT) [4,7]. Consumer behavior has been characterized as being influenced by internal and external factors. Given the penetration of the Internet for retail businesses, the marketing of products has been exponential [8-10]. Electronic commerce (e-commerce) has emerged from this phenomenon, along with a wide variety of sales channels based on digital platforms that range from a website to the use of social media [11]. These businesses have had to face challenges and opportunities manifested by the different types of online consumers [12], including design, security, trust, risk, uncertainty, and satisfaction with online purchases $[13,14]$. These manifestations have been studied from the theory of technological adaptation, which is one of the great milestones for companies and online consumers [12,15]. In addition, one of the external factors influencing the behaviors and intentions of buyers includes issues related to the economic, political, social, environmental, and health aspects. Regarding health, many researchers have not focused on their analysis as a determining element in the change in consumer behavior $[16,17]$. However, as a result of the emergence of the coronavirus pandemic (COVID-19), the behaviors, customs, and lifestyles of the world population and consumers have significantly changed [18-20] due to product shortages, rising prices, lack of supply chain coverage, and the restriction on traditional methods of delivering products to customers, with some businesses lacking to-go services and digital sales platforms $[20,21]$. These factors have been provoking hysteria, fear, panic, and excess purchases, but they have also motivated people to be more responsible consumers $[17,22,23]$. These events and implications have driven most companies of different sizes, including retail stores, to implement strategies based on the adoption of new technologies in their online sales processes and the delivery of products through pickup service implementation $[24,25]$. For this reason, many companies have migrated toward open innovation; that is, they not only pay attention to the products, processes, and services they design, but also attempt to modify their models of doing business based on innovation, considering the capabilities and sources of internal and external knowledge of the company [26,27], all of this to create greater added value for the consumer. Therefore, the technological capacity of business to develop online commerce has become an effective strategy, but its success now depends on the ability to manage open innovation $[28,29]$. In the review of the literature, we verified that two studies analyzed mostly panic buyers, but gaps exist in the context of the socially responsible buyer [23,30]. Therefore, our study provides important theoretical and empirical contributions: (1) the proposed model analyzes and encompasses two types of consumers, socially responsible and panic buyers, from the perspective of BTR and SIT, analyzing the behaviors and norms of these groups of buyers; (2) the model analyzes the level of satisfaction of the two types of buyers from the perspective of adaptation to technology through security in websites use for online purchase transactions. The technological adaptation model (TAM; utility and technological ease of use) best aligns to the theories under study and promotes the development of electronic commerce (e-commerce) [31,32].

According to the World Health Organization [33], in a global context, from the confirmation of the first cases of COVID-19 to 10 December, 2020, 68,165,877 confirmed cumulative cases of COVID-19 have been reported, including 1,557,385 deaths worldwide, representing a total of 18,587,287 additional confirmed cases of COVID-19, including 311,668 deaths, since the last epidemiological update published in November 2020. In the context of the American continent, in the 7 weeks between 29 October and 9 December in all subregions, a relative increase was observed both in the number of cases and in the number of deaths. In North America, the largest increase was observed, with 6,698,515 additional cases and 81,262 additional deaths, representing relative increases of $40 \%$ and $20 \%$, 
respectively. The rest of the subregions increased as follows, in decreasing order: Central America, with a $23 \%$ increase in cases and a $17 \%$ increase in deaths; South America, with an $18 \%$ increase in cases and a 13\% increase in deaths; and the Caribbean Islands and the Atlantic Ocean, with a $12 \%$ increase in cases and a $14 \%$ increase in deaths. In addition, these impacts on Latin American society in Mexico include exponential increase in infections from this pandemic [33]. This has resulted in the closure of multiple businesses and the dismissal of many people. However, despite these hard blows to the Mexican society and economy, some companies have adopted the use of new technologies to provide sales through digital platforms (Facebook, WhatsApp, and websites) to comply with current consumer demands [34]. In Mexico, a number of people with access to the Internet must be reached; it is estimated that around $56 \%$ have access to an Internet connection [35]. In addition, e-commerce trends in Mexico show that online sales will increase by $60 \%$ in 2020 [34]. Our study provides important theoretical and empirical contributions because in the Latin American context and in an emerging economy, this type of analysis during the COVID-19 pandemic adds to the development of the consumer behavior literature and technological adaptation.

Our research objectives were as follows: (1) to determine the influence of the security level of websites on purchasing behaviors (socially responsible and panic buyers), (2) to determine the effect of website security on the consumer satisfaction, (3) to determine the effect of buyers (socially responsible and panic) on the level of satisfaction, and (4) to examine if the buyer experience has a moderating effect between the social responsible and panic buyer variables and the dependent variable (customer satisfaction). The manuscript is structured as follows: first, the literature is reviewed, then the hypotheses are developed, followed by a description of the method (sample, questionnaire, and variables), the results, the conclusions, and discussion.

\section{Literature Review and Hypothesis}

This research has its theoretical basis in the disciplines that analyze consumer behavior and its relationship with the adoption of new information and communication technologies in conducting commercial transactions on the Internet. The new business models based on the new technologies in a fully capitalist and collaborative economy are driving entrepreneurs to join a dynamic, cyclical, creative, and innovative business culture $[36,37]$. Technological capabilities are a fundamental part of the new business models based on the open innovation strategy and are the key factors influencing the satisfaction of online consumers $[38,39]$. The theory of full behavior is based on the analysis of the attitudes and behaviors of the individual in the face of a particular phenomenon. At present, this theory is one of the most used in the context of consumer behavior $[1,40]$. The theory of planned behavior (TPB), from the conceptual point of view, independently integrates three types of intentions. First, the attitude toward behavior is the degree to which a person has a favorable or unfavorable assessment behavior of the phenomenon under analysis. The second is the social factor, which is called subjective norm; this encompasses the perceived social pressure to perform or not perform the behavior. Finally, the antecedent of intention emphasizes the level of behavioral control perceived, which is related to past events and refers to the perceived ease or difficulty of the behavior, reflecting the experience of facing obstacles in the present $[1,5]$. Therefore, these conceptual considerations significantly affect consumer behavior because the relative importance of attitude, subjective norms, and perceived behavioral control varies according to the real situations of the individual [40].

In general, consumer behavior is analyzed from two disciplines: social sciences and business sciences (marketing) [41,42]. These studies have focused on arguments derived from the behavioral reasoning theory (BRT), a new theory in the field of marketing that tries to link attitudes, beliefs, behaviors, reasoning, and subjective norms in favor and against consumer purchasing intentions $[7,8,43]$. Social identity theory (SIT) analyzes the behaviors of a social group that are directed toward the responsible actions carried out by an 
individual for a common good. In the context of consumer behavior, this theory is closely linked to the socially responsible behaviors of the inhabitants of a community [44,45]. In addition, this theory is closely linked with other theories that analyze the behavior, norms, and behaviors of individuals collectively; one of these is related to environmental and sustainable behavior $[46,47]$. These theories are linked to the technology acceptance model, which is focused on measuring the utility and ease perceived by the user when making an online purchase (e-commerce) through different electronic devices, including desktop computers, laptop, electronic tablets, and smartphones (e-mobile).

\subsection{Website Security and Responsible and Panic Buyers}

In the literature, a wide variety of models have been used to analyze information systems and their impact on purchasing behavior. One of the pioneering models in this field of action is that constructed by DeLone and McLean [48], which considers quality factors and the use, benefits, and the security of information systems as key factors satisfying the needs of consumers. Derived from these contributions, the technological adaptation model (TAM) arose, which considers ease of use and utility perceived by the consumer [49], being one of the theoretical models most widely used to measure online consumer satisfaction [50]. Technological changes and increased dependence on the Internet have been shaping the buying behavior of consumers, forcing most companies to develop electronic commerce through the establishment of virtual stores or online websites [15,51]. However, one of the elements determining the achievement of trust and reputation is the correct use of computer media and systems by businesses to provide high security [52,53]. The TAM and other models focusing on customer satisfaction have tried to cover the following aspects in e-commerce or, more recently, commerce through mobile (e-mobile) [53,54]: compliance, customer service, and consumer security (privacy) [53]. Therefore, the security of the website, the quality of the website, the satisfaction of online consumers, and the ability to learn are and will continue to be determining factors in the analysis of purchasing behavior [52,55].

Consumers have become individuals with greater demands and with attitudes oriented toward social responsibility [23]. Therefore, many consumers are evaluating the sustainable practices that businesses are developing to make purchase decisions based on values and morals [56]. Some researchers have expressed that the safety and reputation of the website is decisive for the purchasing intentions of the responsible consumer [56]. However, other studies reported that socially responsible consumers perceive a greater risk of buying online and confidence is lacking in the security of websites [57]. In more recent studies, researchers have found that the behaviors of socially responsible online consumers are drastically changing and relying on online shopping due to the emergence of new electronic commerce platforms, such as collaborative e-commerce, the pickup mode, and the use of social media (Facebook and WhatsApp)—online sales channels that are linked to the business website [58-60]. These strategies have been a key element in promoting online purchases by responsible consumers, encouraging the purchase of ecological, economical, recyclable, and sustainable products, mainly due to the social influence of communities that have already had experience with online shopping [61,62]. Another classification of consumers is that of the panic buyer, who is characterized as an individual with variable behavior due to various factors, such as cultural, social, shortage of products, political, economic, and health factors $[16,17,20]$. During the COVID-19 pandemic, these types of consumers are being strongly influenced by the information on digital social networks [31,63]. Due to confinement, traditional sales channels are no longer the preferred means of purchasing products for consumers; therefore, panicked consumers have increased their trust in digital platforms and in companies' websites when conducting their business online shopping [64]. Some recent studies concluded that online shopping experiences have helped other buyers reduce their risk and fear when using websites and other digital platforms [64]. Given the theoretical context and empirical argumentation, the following research hypotheses are proposed: 
Hypothesis 1 (H1). A higher level of website security has a positive and significant effect on the behavior of the socially responsible online buyer.

Hypothesis 2 (H2). A higher level of website security has a positive and significant effect on the behavior of the online panic buyer.

\subsection{Website Security and Consumer Satisfaction}

In this new current scenario, open innovation through business technological capacity is and will be one of the most successful strategies in the design, security, and ease of use of website and technological platforms for the development of e-commerce $[65,66]$. In the literature, various theories and models have been used to analyze the e-commerce through companies' websites, with the TAM and BRT being the most used and the central elements that link the security of a company website with consumer satisfaction [52]. Studies in this context have expressed that both the security and usability of the website are decisive in achieving maximum online consumer satisfaction [67,68]. Rita et al. [54], concluded that overall consumer satisfaction with online commerce is significantly affected by the security and trust provided by a website. Other studies have shown that with the growth in commerce through e-mobile, online consumers are increasing, but losing the privacy of their personal data [69], but in other cases, increasing its level of use and confidence [70]. In another direction, in the purchases completed through desktop and/or laptop computers, consumers have higher confidence and security in the use of websites for online purchases [71,72]. Elements that measure the quality of the design, the security, and the usability of the websites are key to increasing the satisfaction of the majority of consumers online, also directly affecting the intentions of future purchases [66,73]. From the theoretical context and empirical argumentation, the following research hypothesis is proposed:

Hypothesis 3 (H3). A higher level of website security has a positive and significant effect on online consumer satisfaction.

\subsection{Socially Responsible Buyers, Panic Buyers, and the Level of Satisfaction}

Starting from SIT and BRT, we analyze the interaction of different types of online consumers on the level of satisfaction. From an organizational point of view, companies are adopting sustainable practices that lead them to gain market share, increase reputation, and raise the expectations of their consumers [74]. From the consumer viewpoint, socially responsible buyers are emerging more frequently [75]. Various studies have shown that socially responsible consumers have a higher level of satisfaction when they make their purchases from companies with good social, economic, and environmental practices [76]. Other studies have argued that socially responsible buyers are looking for green products and reputable brands $[77,78]$. In addition, socially responsible consumers display ethical and altruistic behavior, derived from the responsible purchases they make from sustainable companies, which in turn positively affect their purchase intentions and the level of satisfaction $[79,80]$. Therefore, when these consumers have negative experiences with their online purchases, their recommendations to other potential consumers become a key factor in their purchase intentions and satisfaction levels [25,81]. However, other studies associating the level of satisfaction with responsible online buyers were derived from behaviors related to fear and religiosity, practices that lead them to be environmentally friendly and responsible individuals [82].

Regarding the relationship between panic buyers and the level of satisfaction, various studies have emerged during the COVID-19 pandemic. In some cases, social influences, product shortages, and stress due to economic uncertainty were found to generate hysteria and low levels of satisfaction with online purchases [83]. As a result, online panic consumers face serious problems in their economy and in their daily habits; therefore, purchases have decreased and prices have increased; with this, the level of consumer satisfaction has decreased $[19,84]$. Therefore, online panic buyers perceive many obstacles 
and risks regarding perceived value because the level of satisfaction is associated with the attention and quality they receive from sellers (online stores) [31,85].

With this same context, the behaviors of compulsive buyers, despite having certain distinctive personality traits, are being modified by social, economic, cultural, and technological factors [20]. Recent studies in different regions have confirmed that the shortage of products and confinement have been the strongest triggers increasing the intention of compulsive buyers to buy online through different digital platforms; consequently, they do not assign much importance to the level of satisfaction. The focus is on meeting a need derived from intrinsic impulses $[31,64,83]$. The variety of online shopping channels is forcing companies to pay more attention to quality of service [86]. Similarly, other researchers have concluded that compulsive buyers are focusing on other factors that encourage unplanned purchases; therefore, being in fear of the COVID-19 pandemic, a positive or significant correlation with the level of satisfaction has not been perceived $[23,87]$. From the theoretical and empirical review, the following hypothetical approaches were structured (Figure 1):

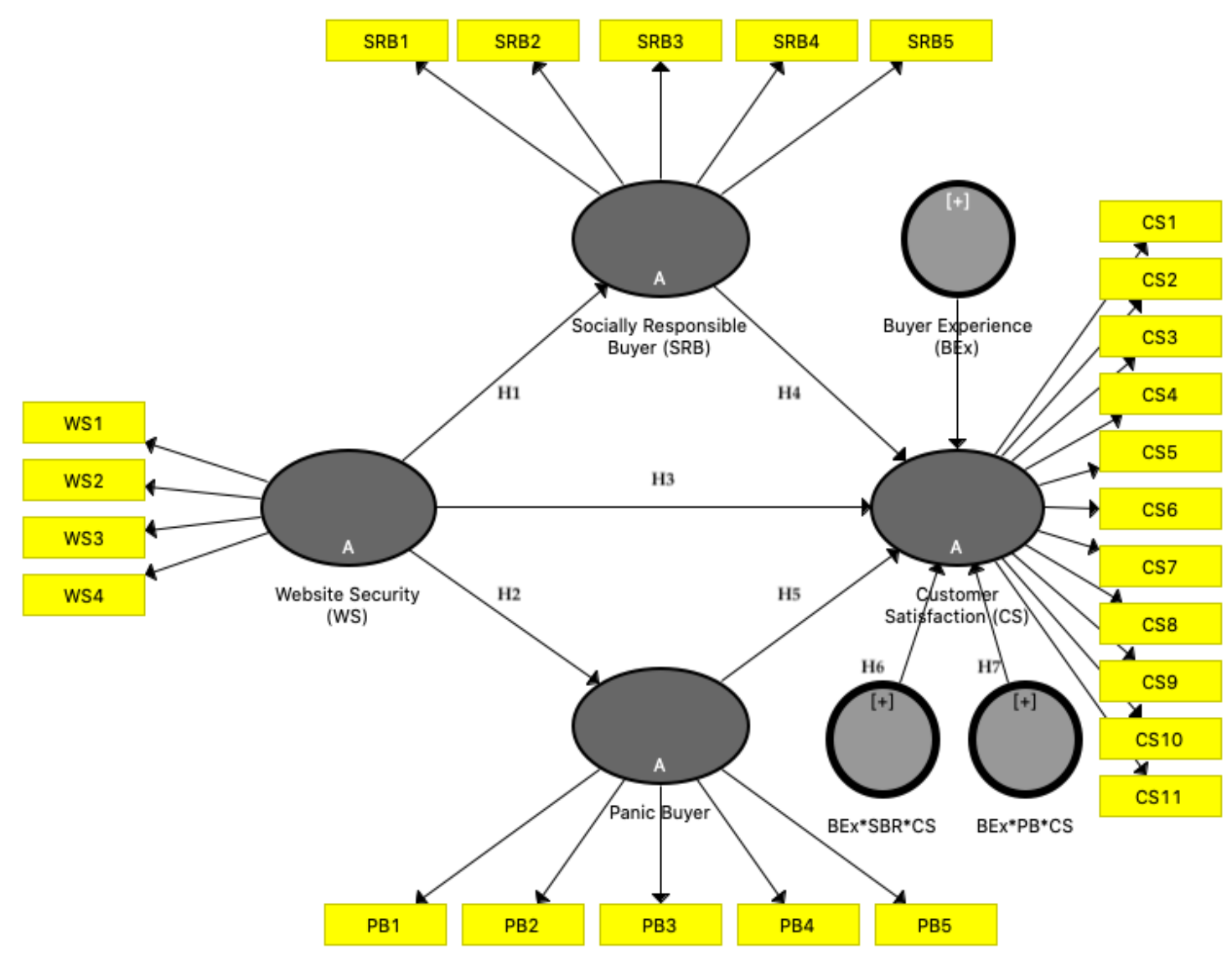

Figure 1. Theoretical research model.

Hypothesis 4 (H4). A higher level of socially responsible purchases increased the level of online shopping satisfaction.

Hypothesis 5 (H5). A higher level of panic purchases increases the level of online shopping satisfaction.

\subsection{The Socially Responsible Buyer and Panic Buyer Experience, and Customer Satisfaction}

One of the key factors for measuring the use and perceived benefit of online buyers is satisfaction with their shopping experience. This indicator has become the central axis of e-commerce and modern marketing strategies. Therefore, the experience with a website is determined by tangible and intangible elements such as: the security of the website; its functionality, ease of use, and design; the type of products or services; the prices; the reputation of the brand; sensations and emotions; and decisions affecting the level of consumer 
satisfaction. Constantinides [88], on the experience of online shopping, found that the functionality of a website includes elements related to the usability of the site and interactivity, psychological elements aimed at reducing customer uncertainty by communicating the trust and credibility of the online and website provider, and content elements, including esthetic aspects of the online presentation and marketing mix. Similarly, other studies reported that the perceived value, such as innovation, technology, and the perceived risk, as the interaction and effective communication between buyer and seller, are the factors determining cultivation of online customer satisfaction [89]. Javed and $\mathrm{Wu}$ [90] and Obina-Ramírez et al. [91] found that the recommendations of other online consumers were the experiences with the greatest recurrence by socially responsible consumers, in addition to the trust of the website, the guarantees, and the refunds with which companies manage to positively influence the level of satisfaction. Panic purchases have increased since the emergence of the COVID-19 pandemic, which has led to a general increase in prices, product depletion, and fear due to economic and social uncertainty [92]. Therefore, this phenomenon has stimulated consumer behavior to buy products not only essential for daily life [83]. The greater the fear caused by external phenomena such as the COVID-19 pandemic, the greater the frequency of the shopping experience that is not related to the level of customer satisfaction $[20,93]$. In addition, panic and unfulfilled purchases have been affected by the huge amount of online advertising; with it, the shopping experience has significantly affected the satisfaction of online buyers [94]. The COVID-19 pandemic has motivated online consumers to worry more about basic needs such as food for consumption than about other types of non-required needs during this global health and economic crisis [95]. Therefore, the shopping experience based on emotions, recommendations, and past evaluations becomes a determining factor positively influencing purchase intentions and the level of online customer satisfaction [96,97]. From the theoretical and empirical review, the following hypothetical approaches were structured (Figure 1):

Hypothesis 6 (H6). Buyer experience has a significant moderating effect between socially responsible buyers and the level of satisfaction.

Hypothesis 7 (H7). Buyer experience has a significant moderating effect between panic buyers and the level of satisfaction.

\subsection{Explanation of Our Theoretical Model}

Figure 1 depicts the operating model of this investigation, displaying each of the structural relationships (hypotheses) contemplated in this study. The model has its theoretical foundation in the theoretical currents of the TAM, BRT, and SIT models. Therefore, we aimed to analyze the effects of website security on socially responsible buyers, panic buyers, and their behavior in the level of satisfaction. All these relationships are described in $\mathrm{H} 1$ to H5. The model presents the moderating effect of the online shopping experience between the two types of buyers with respect to their level of satisfaction (H6 and H7).

\section{Methodology}

\subsection{Population and Sample}

This research study was a cross-sectional quantitative and explanatory study. The subjects participating in the study were analyzed under the principles of stratified sampling. The study population was selected according to the following criteria: (1) access to Internet connectivity, (2) online buyer experience, (3) place of residence, (4) economically active population, and (5) age. The study was developed in the regions of Sonora, Baja California, and Sinaloa in Mexico. In these regions, there is an economically active population of $2,485,823$ between the ages of 20 and 55 years [98]. Of this population, $70 \%$ have access to the Internet [99]. To determine the sample, the probability in favor of $50 \%$ and against $50 \%$, a confidence level of $95 \%$, and an estimation error of $3.8 \%$ were considered. The sample in this study included 663 people who responded to an online survey, which was adminis- 
tered through Google forms during the months of confinement caused by the COVID-19 pandemic (from April to August 2020), of which $45 \%$ correspond to consumers resident in the Sonora region, 35\% in the Baja California region, and 20\% in the Sinaloa region in Mexico. Tables 1 and 2 list the characteristics of the study subjects.

Table 1. Sex and age of the sample.

\begin{tabular}{ccccc}
\hline \multicolumn{5}{c}{ Age (Years) } \\
\hline Sex & $\mathbf{2 0}$ to $\mathbf{3 0}$ & $\mathbf{3 1}$ to $\mathbf{4 5}$ & $\mathbf{4 6}$ to $\mathbf{5 5}$ & Total \\
\hline Female & 250 & 138 & 65 & 453 \\
Male & 97 & 62 & 51 & 210 \\
Total & 347 & 200 & 116 & 663 \\
\hline
\end{tabular}

Table 2. Age and electronic device use of the study sample.

\begin{tabular}{cccccc}
\hline Age (Years) & Smartphone & Laptop & Desktop & Electronic Tablet & Total \\
\hline 20 to 30 & 231 & 91 & 15 & 10 & 347 \\
31 to 45 & 117 & 59 & 21 & 3 & 200 \\
46 to 55 & 47 & 41 & 24 & 4 & 116 \\
Total & 395 & 191 & 60 & 17 & 663 \\
\hline
\end{tabular}

\subsection{Validation of the Questionnaire}

Different tests were conducted to validate the questionnaire used in the research. The content validity was determined using the theories that supported the study, which are directed toward purchasing behavior and the use and adaptation to technologies. The content validation of the questionnaire is one of the most important phases to correctly measure a construct or a dimension [100]. This phase was performed through a thorough review of the literature to correctly define the dimensions contemplated by the questionnaire and its adaptation to the regional context of the study. The questionnaire was divided into two phases: the first included questions regarding general or demographic data (age, sex, education, place of residence, buyer experience, frequency of purchase, type of electronic device, digital purchasing platform, among others); the second phase included questions related to website security (4 items), socially responsible buyers ( 8 items), panic buyers (5 items), and customer satisfaction (11 items). For this purpose, for the development of items of the website security dimension, several studies related to the TAM were analyzed; for the items of the socially responsible buyer dimension, studies aligned with the theory of social identity were considered; the panic buyer dimension was based on studies related to behavioral reasoning theory; and for the customer satisfaction dimension, the theories of the TAM and behavioral reasoning theory were applied (the details of the measurement at the construct level of the variables are provided in Section 3.3). The questionnaire was validated by a panel of experts in the marketing area (2 researchers from the Autonomous University of Baja California in Mexico, 2 research professors from the Technological Institute of Sonora in Mexico, and 1 research professor from the University of Extremadura in Spain) to issue recommendations on the design of the dimensions, relevance, and representativeness of each of the questions. Through the content validity index, the group of experts evaluated each of the items of the different dimensions on a scale from 1 to 5 , where 1 indicated not very relevant and 5 indicated very relevant [101]. For the questions included in the questionnaire, the value of each question had to obtain a weighted average score of 4 , and $80 \%$ of the experts had to agree with it; that is, that at least 4 of the experts had to evaluate the questions in a similar way for the question to not be eliminated from the questionnaire.

A pilot test was conducted with $5 \%$ of the total of the sample to correct possible errors in the writing and understanding of the questions in the questionnaire [102]. The study subjects (online consumers) from the different regions participating in the study who 
responded to this questionnaire from the pilot test were randomly chosen according to the characteristics required in the sample, which was sent via email in April 2020.

A factor analysis was carried out and the Harman single factor test (common method of variance (CMV)) was necessary to perform the following procedures: (1) run a factor analysis of all the exogenous latent and endogenous latent constructs of the model, and then an analysis of the main components without selecting any type of rotation method; and (2) the values of the non-rotated components and the number of factors that complement the variance were analyzed $[103,104]$. The results of this test were (1) the model is grouped by 4 factors, (2) the Kaiser-Meyer-Olkin (KMO) indicator was 0.895 and significant at $99 \%$, and (3) the total variance explained was $61.69 \%$. In addition, the explained variance of the first factor $(26.19 \%)$ was less than the total explained variance, thereby ruling out the presence of response bias. These analyses provided the preamble for the statistical validation and measurement of the internal consistency of the constructs, which were developed within the measurement model phase through the modeling of the structural equation system with the partial least square-SEM (PLS-SE) analyses in Section 3.3.

\subsection{Measurement of Variables}

Next, we describe the measurement of the variables of the research model. All variables were measured under the reflective type constructs approach in mode A and under the one-dimensional variable approach. These types of variables have particular characteristics such as (1) the direction of causality is from the construct to the indicators, (2) the indicators are highly correlated, (3) eliminating an indicator does not alter the meaning of the construct, and (4) these types of measures are recommended for a model with constructs focused on the analysis of behavioral sciences [105]. The constructs that were used in the research model are described below. The items of the questionnaire were designed under a 7-point Likert-type scale (1, completely disagree, to 7, completely agree).

\subsubsection{Website Security (WS)}

This variable was measured considering the behavioral reasoning theory and the model of technological adaptation [4,15]. The construct is composed of 4 questions: (1) The website inspires security, (2) The website protects personal data, (3) The website makes good use of personal data, and (4) The website has secure banking transactions. For its design and adaptation, we considered the studies by Lee and Turban [106], Pavlou [31], and Blut [53]. The reliability and validity indicators of the variable were Cronbach's $\alpha=0.744$, factor loading $=0.703$ to 0.788 , composite reliability $=0.835$, and average extracted variance $=0.559$.

\subsubsection{Socially Responsible Buyer (SRB)}

This variable was measured considering the theory of social identity [45] and the model of technological adaptation [15]. The construct was composed of 5 questions: (1) I try to reuse the products I have bought, (2) I buy products that do not harm the environment, (3) I buy products in support of social causes, and (4) I buy products from socially responsible companies. For its design and adaptation, we used Diamantopoulos et al. [107], Barbarossa and De Pelsmacker [108], and Buerke et al. [109] as references. The validity indicators of the variable were Cronbach's $\alpha=0.837$, factor loading $=0.747$ to 0.866 , composite reliability $=0.892$, and average extracted variance $=0.674$.

\subsubsection{Panic Buyer (PB)}

This variable was measured considering the behavioral reasoning theory and the model of technological adaptation $[4,7,15]$. The construct was composed of 5 questions: (1) I buy items due to fear of scarcity, (2) I buy products due to fear of price increases, (3) I buy products due to social influence (social media), (4) I buy products out of fear of an economic crisis, and (5) I buy products out of fear of being contaminated by the COVID19 pandemic. For its adaptation and design, Kukar-Kinney et al. [23], Arafat et al. [18], and Laato et al. [20] were considered. The reliability and validity indicators of the variable 
were Cronbach's $\alpha=0.880$, factor loading $=0.759$ to 0.848 , composite reliability $=0.902$, and average extracted variance $=0.647$.

\subsubsection{Customer Satisfaction (CS)}

This variable was measured considering the theory of reasoned action and the model of technological adaptation $[4,7,15]$. The construct was composed of 11 questions related to the satisfaction with the website: (1) The information on the website is accurate, (2) The information on the website is high quality, (3) Ease of interaction with the website, (4) I enjoy shopping on the website, (5) Fast delivery of the products, (6) There are competitive prices, (7) The website has a good reputation, (8) There is a wide variety of products, (9) The technological innovation of the website is high, (10) The website has a good corporate image, and (11) Quick and timely service. For its design and adaptation, we considered the studies of Zeithami et al. [110] and Hausman and Siekpe [111]. The validity indicators were Cronbach's $\alpha=0.880$, factor loading $=0.759$ to 0.848 , composite reliability $=0.902$, and average variance extracted $(\mathrm{AVE})=0.647$.

\subsubsection{Buyer Experience (BEx)}

Traditionally, buyer experience has been measured by the benefits and perceived value of the products or services they have purchased $[73,88]$. For our study, we considered the measurement of this variable as a moderating factor between the two types of buyers and the level of satisfaction. To do this, we divided the shopping experience into 2 groups: (1) little experience (less than 3 years of experience with online purchases) and (2) experienced (more than 3 years of experience with online purchases). In addition, the products they have bought in the last three months include: $57 \%$ basic consumer products, $19 \%$ clothing and accessories, $12 \%$ prepared foods, and 12\% electronic products.

\subsection{Discriminant Validity of the Model}

We considered the suggestions by Fornell and Larcker [112] and Henseler et al. [113]: the amount of variance captured by a construct from its indicators (AVE) must be greater than the variance shared by the construct with other constructs. The (diagonal) results of the vertical and horizontal AVE in Table 3 show the correlation between the constructs.

Table 3. Discriminant validity (criterion: Fornell and Larcker [112]). AVE, average variance extracted.

\begin{tabular}{cccccc}
\hline Construct & AVE & CS & PB & SRB & WS \\
\hline Customer Satisfaction (CS) & 0.601 & 0.775 & & & \\
Panic Buyer (PB) & 0.647 & 0.073 & 0.804 & & \\
Socially Responsible Buyer (SRB) & 0.644 & 0.311 & 0.161 & 0.803 & \\
Website Security (WS) & 0.557 & 0.434 & 0.144 & 0.205 & 0.746 \\
\hline
\end{tabular}

Recently, studies on the subject of discriminant validity have expressed that the FornellLarcker criterion has deficiencies. Therefore, we decided to analyze the heterotrait-monotrait ratio (HTMT), a method that represents the average of the heterotrait-heteromethod correlations in relation to the average of the monotrait-heteromethod correlations [114]. Therefore, the value of HTMT should be less than 1 . Table 4 shows that our values are below 1 , thereby confirming the discriminant validity of the model [115].

Table 4. Discriminant validity (heterotrait-monotrait ratio (HTMT)).

\begin{tabular}{cccccc}
\hline Construct & AVE & CS & PB & SBR & WS \\
\hline Customer Satisfaction (CS) & 0.601 & & & & \\
Panic Buyer (PB) & 0.647 & 0.091 & & & \\
Socially Responsible Buyer (SRB) & 0.644 & 0.338 & 0.194 & & \\
Website Security (WS) & 0.557 & 0.479 & 0.150 & 0.246 & \\
\hline
\end{tabular}




\section{Results}

This section presents the results of the structural model of our investigation. The structural equation modeling (SEM) system based on variance was used to test the hypotheses of the model as the variables focused on analyzing consumer behavior online (Section 3.1). Experts in the methodology (SEM) and in partial least square (PLS) have concluded that this technique is recommended for the analysis of phenomena in business sciences, marketing, and information systems [116-118]. For the structural analysis of the data, it is required to evaluate: (1) the magnitude, the algebraic sign, and the significance of the path coefficients; (2) the one-tailed Student's t-test with n-1 degrees of freedom; and (3) the confidence intervals (percentile and bias-corrected) [118]. To obtain these indicators, a bootstrapping test with 5000 sub-samples is required $[119,120]$.

Table 5 shows the results of the model hypotheses $\mathrm{H} 1, \mathrm{H} 2, \mathrm{H} 3$ and $\mathrm{H} 4$; the path coefficients have a positive and significant effect at $99 \%$. For $\mathrm{H} 5$, no empirical support was found. The SD, $t$-value greater than two, the confidence intervals in percentiles and bias-corrected (did not show a value of 0 ) are also displayed.

Table 5. Model hypothesis testing.

\begin{tabular}{cccccccccc}
\hline Hypothesis & Path Coefficient & SD & T Score & F $^{\mathbf{2}}$ & CI 5-95\% & $\begin{array}{c}\text { Bias Corrected } \\
\mathbf{5 \%} \text { CI }\end{array}$ & 95\% CI & Result \\
\hline H1: WS $\rightarrow$ SRB & $0.205^{* * *}$ & 0.040 & 5.096 & 0.000 & 0.044 & 0.137 & 0.268 & 0.133 & Supported \\
H2: WS $\rightarrow$ PB & $0.144^{* * *}$ & 0.043 & 3.345 & 0.001 & 0.021 & -0.002 & 0.190 & 0.022 & Supported \\
H3: WS $\rightarrow$ CS & $0.388^{* * *}$ & 0.035 & 11.178 & 0.000 & 0.188 & 0.327 & 0.443 & 0.328 & Supported \\
H4: SRB $\rightarrow$ CS & $0.235^{* * *}$ & 0.043 & 5.503 & 0.000 & 0.068 & 0.163 & 0.302 & 0.163 & Supported \\
H5: PB $\rightarrow$ CS & -0.020 & 0.053 & 0.379 & 0.705 & 0.004 & -0.136 & 0.052 & -0.124 & Unsupported \\
\hline
\end{tabular}

Note that $\mathrm{n}=5000$ subsamples: ${ }^{* * *} p<0.001$ (one-tailed Student's $t$-test), t $(0.05 ; 4999)=1645 ; \mathrm{t}(0.01 ; 4999)=2327 ; \mathrm{t}(0.001 ; 4999)=3092$.

To evaluate the quality, relevance, and fit of the model, the adjusted coefficient of determination $\left(\mathrm{R}^{2}\right)$ values were analyzed: $\mathrm{SRB}=0.041, \mathrm{~PB}=0.019$, and $\mathrm{CS}=0.237$, with the recommended (Stone-Geisser test) $\mathrm{Q}^{2}$ value $>0$ [121]. the values of the independent variables are: $\mathrm{SRB}=0.026, \mathrm{~PB}=0.010$ and $\mathrm{CS}=0.137$; standardized root mean square residual (SRMR) is recommended to be $>0.08[122,123]$. Our result was 0.069 . Normed fit index (NFI) values close to 0.9 are recommended, our result was 0.838 . The recommended root mean square error correlation (RMStheta) value is $<0.12$ [124]; our result was 0.129 . According to these tests, the proposed theoretical model has an acceptable quality, predictive relevance, and is adjusted to the theory.

\subsection{Results of the Moderating Effect}

Moderation describes a situation in which the relationship between two constructs is not constant but depends on the values of a third variable, called the moderating variable. The moderating variable (or construct) changes the strength or even the direction of a relationship between two constructs in the model [125].

Table 6 and Figure 2 show the results of the moderating effect. H6 was not supported; so, in this study, the buyer experience did not have any significant effect between panic buyers and customer satisfaction. H7 was supported, showing that the buyer experience has a significant negative effect between socially responsible buyers and customer satisfaction. In addition, we observed that in the global model, the value of the adjusted $\mathrm{R}$ was slightly increased by incorporating the moderating variable buyer experience from 0.237 to 0.259 . 
Table 6. Model hypothesis test (moderating effect).

\begin{tabular}{cccccc}
\hline Hypothesis & $\begin{array}{c}\text { Path } \\
\text { Coefficient }\end{array}$ & SD & T Score & $p$-Value & Result \\
\hline H6: Buyer Experience $\times \mathrm{PB}^{*} \rightarrow \mathrm{CS}$ & $-0.007 \mathrm{~ns}$ & 0.052 & 0.133 & 0.894 & Unsupported \\
H7: Buyer Experience $\times \mathrm{SBR} \rightarrow \mathrm{CS}$ & $-0.103^{* *}$ & 0.041 & 2.516 & 0.012 & Supported \\
\hline Note: $\mathrm{n}=5000$ subsamples: ${ }^{*} p<0.05$; $^{* *} p<0.01$; ns: non-significant. & & &
\end{tabular}

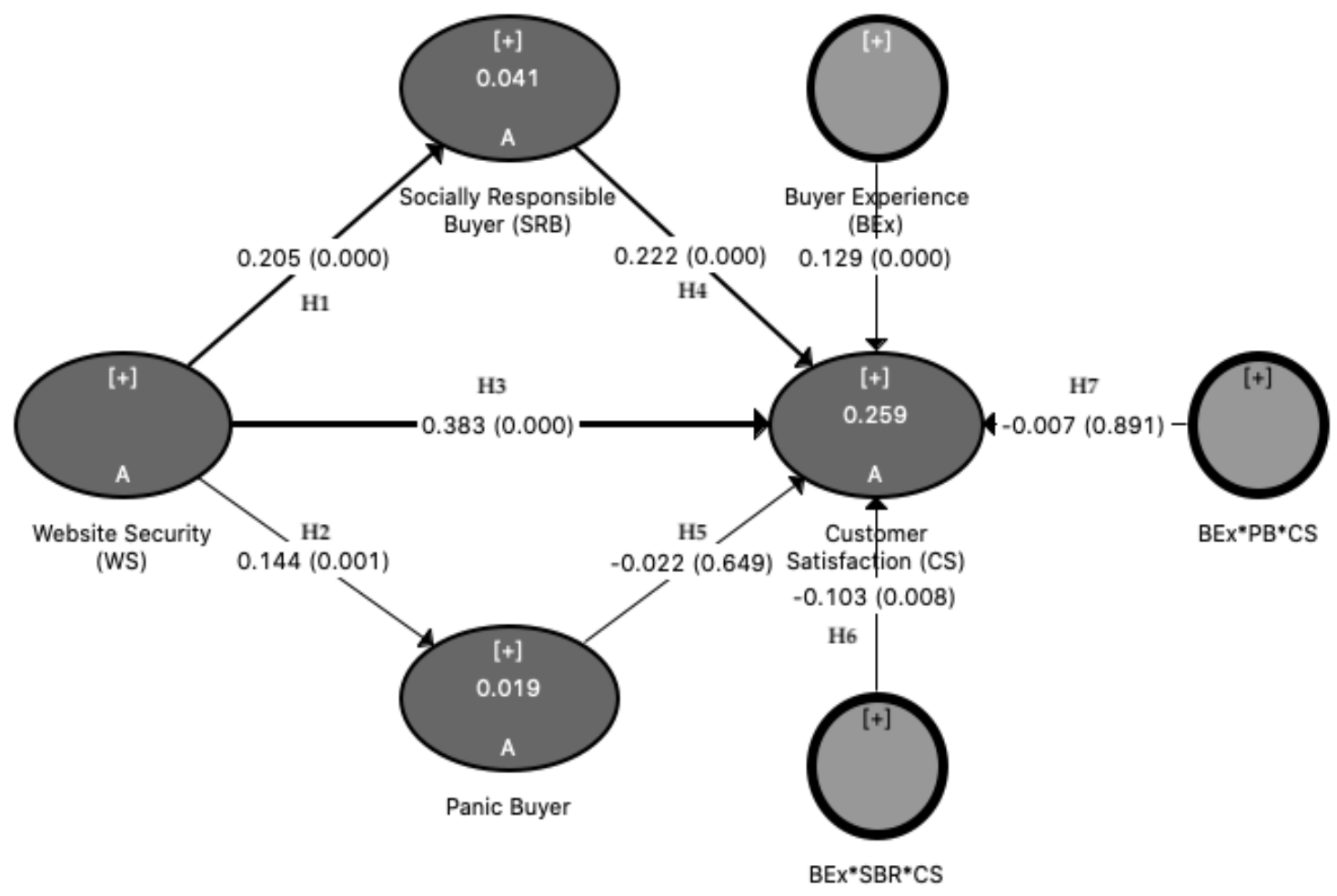

Figure 2. Moderating effect in the theoretical model.

\subsection{Multi-Group Analysis}

PLS-multi-group analysis (PLS-MGA) was used to measure the impact or moderation of a categorical variable that can manifest in two or more groups. This type of analysis is used to compare significant differences between the groups that are being compared. In this study, we analyzed two groups of online shoppers: Group 1 buyers (G1) with less than 3 years of experience in transactions using e-commerce, and Group 2 buyers (G2) with more than 3 years of experience in transactions using e-commerce.

In this study, the non-parametric PLS-MGA was used. This test requires confirmation of the measurement invariance between the two groups. For this, the configurational invariance and compositional invariance were analyzed [126]. Regarding the configurational invariance, we confirmed that the treatment of the data for the measurement of the two models and the structural configuration and the algorithm were the same for both groups (Table 7). For compositional invariance, a permutation method was performed with a sample of a minimum of 1000 permutations with a significance level of $5 \%$.

We used this method to compare the original score correlations with the correlations obtained from the empirical distribution after running the permutation process. Therefore, if correlations exceed $5 \%$, there is compositional invariance. Table 8 provides the results of the differences in the path coefficients and the level of significance for each of the hypotheses of the model. In $\mathrm{H} 4$ and $\mathrm{H} 5$, there were significant differences. Therefore, we inferred that the less the shopping experience, the more the level of satisfaction increases. This may be caused by buyers who have recently experienced purchases of products and 
services related to environmental and ecological actions being less demanding than buyers with more experience in these purchases. Experienced panic buyers were likely to have a higher level of satisfaction, which may have been caused by the benefits and perceived value at the time of making their purchase, considering this action as a basic necessity.

Table 7. Configurational invariance and the compositional invariance of the theoretical model.

\begin{tabular}{cccccc}
\hline Construct & Correlation & $\begin{array}{c}\text { Correlation of } \\
\text { Permutation Means }\end{array}$ & $\mathbf{5 . 0 \%}$ & $\boldsymbol{p}$-Value & $\begin{array}{c}\text { Result of } \\
\text { Invariance }\end{array}$ \\
\hline CS & 0.994 & 0.998 & 0.997 & 0.057 & Yes \\
PB & 0.942 & 0.841 & 0.439 & 0.722 & Yes \\
SRB & 0.978 & 0.993 & 0.979 & 0.062 & Yes \\
WS & 0.999 & 0.987 & 0.962 & 0.988 & Yes \\
\hline
\end{tabular}

Table 8. Path coefficients, $t$-value, and $p$-value.

\begin{tabular}{ccccc}
\hline Hypothesis & Path G1-G2 & T-Value (G1 vs. G2) & $\boldsymbol{p}$-Value (G1 vs. G2) & Results \\
\hline H1: WS $\rightarrow$ SRB & 0.002 & 0.436 & 0.872 & Not significant \\
H2: WS $\rightarrow$ PB & 0.116 & 0.176 & 0.352 & Not significant \\
H3: WS $\rightarrow$ CS & 0.002 & 0.481 & 0.962 & Not significant \\
H4: SRB $\rightarrow$ CS & -0.386 & 0.997 & 0.006 & Significant \\
H5: PB $\rightarrow$ CS & 0.382 & 0.009 & 0.018 & Significant \\
\hline
\end{tabular}

Tables 9 and 10 provide the results of the multi-group analysis through the adjusted $\mathrm{R}^{2}$ value of each of the variables of the proposed model. The findings showed that there were significant differences in customer satisfaction; therefore, we inferred that the buyer experience (little and experienced) does significantly influence the value and benefits perceived through the level of satisfaction of online consumers.

Table 9. Adjusted $R^{2}$ values, $t$-value, and $p$-value comparing groups 1 and 2 .

\begin{tabular}{ccccccc}
\hline Construct & $\boldsymbol{R}^{\mathbf{2}}(\mathrm{G} 1)$ & $\boldsymbol{R}^{\mathbf{2}} \mathbf{( G 2 )}$ & $\boldsymbol{T}$-Value (G1) & $\boldsymbol{T}$-Value (G2) & $\boldsymbol{p}$-Value (G1) & $\boldsymbol{p}$-Value (G2) \\
\hline CS & 0.177 & 0.326 & 2.875 & 5.614 & 0.002 & 0.000 \\
PB & 0.022 & -0.002 & 0.645 & 0.127 & 0.260 & 0.449 \\
SRB & 0.027 & 0.030 & 0.727 & 1.011 & 0.234 & 0.156 \\
\hline
\end{tabular}

Table 10. Difference of groups with adjusted $R^{2}, t$-value, and $p$-value.

\begin{tabular}{cccc}
\hline Construct & R2 (G1-G2) & $p$-Value (G1 vs. G2) & $p$-Value New (G1 vs. G2) \\
\hline CS & -0.148 & 0.955 & 0.090 \\
PB & 0.024 & 0.273 & 0.547 \\
SRB & -0.002 & 0.535 & 0.929 \\
\hline
\end{tabular}

\section{Discussion}

Here, we describe the main findings of the study, which was developed in a pandemic context (COVID-19) unprecedented for humanity and under the premise of online consumers in a developing region. It is important to highlight that the behavior and satisfaction of online consumers in recent decades have a greater dependence on new business models based on innovation, technology and the dynamic capabilities of companies to offer goods and services with a high added value. To fulfil the research objectives and the hypothetical approaches, the findings revealed the following:

We first discuss the findings according to the logical order of the development of the hypotheses of the proposed model; these results were analyzed from the perspective of the technological adaptation model with emphasis on the information security factor and the data that constitute a system business $[15,32]$. H1 showed that the security of the 
website is a factor determining the generation of trust and certainty for socially responsible buyers. This finding agrees with the theoretical and empirical studies that analyzed the behaviors of socially responsible consumers and the connection with the technological adaptation model and behavioral reasoning theory $[7,23,31,53,74]$. New technological platforms for e-commerce have been increasing, moving consumers toward the use of these new devices, which has transformed the behaviors and risks of perceived value for socially responsible buyers $[59,60]$. H2 showed that website security also has a positive and significant effect on panic online buyers, but with less strength than H1. Therefore, website security is one of the key elements that considered by panic buyers when conducting e-commerce operations $[58,63]$. These findings align with the adaptation technology literature and behavioral reasoning theory $[7,66]$. Although compulsive buyers purchase e-commerce products that are not essential, to some extent, they focus on the trust and security of technology platforms such as purchases through websites $[64,83]$. With the emergence of the COVID-19 pandemic, a large number of technological platforms have proliferated, with new business models focused on e-commerce; this has influenced overall behaviors and behaviors of panic online shoppers, leading them to make purchases based on impulse such as fear and uncertainty due to the shortage of basic necessities $[63,64]$. Similarly, the findings have revealed that website security experienced by this type of online buyers has a significant effect on the level of satisfaction $(\mathrm{H} 3)$. Therefore, we verified that increased security, trust, and value perceived by the use of the websites improves the emotional state in the benefits received, which generates an increase in the level of customer satisfaction [52,73]. In addition, online consumers experience the use of new technological platforms to make online purchases every day; this has caused a change in behaviors, placing greater emphasis on the design, trust, usability, security, and content of websites that increase customer satisfaction $[70,73]$.

Next, we analyzed the findings of $\mathrm{H} 4$ and H5. The results showed that when there are more socially responsible buyers, the level of satisfaction of this type of consumer is moderately affected. Based on behavioral reasoning theory and SIT, socially responsible buyers have more subjective norms and behaviors associated with the behaviors of other individuals $[3,4,46]$. For this reason, sometimes the level of satisfaction is associated with external factors such as behavioral paradigms and environmental behaviors of new online business models. The most recurrent strategies of new online businesses are focused on strengthening the image and reputation of the brand through certification processes, secure websites, the use of influencers on social networks, and the adoption of socially responsible practices $[76,80]$. However, our findings showed that panic buyers do not have a significant relationship or effect with the level of online consumer satisfaction. As such, we inferred that panic buyers in scenarios of environmental, health, and economic effects, the benefits and perceived value of the products and services they receive are not a determining factor in performing e-commerce operations $[23,83,94]$.

Thirdly, we analyzed the results of the moderating effect and the multigroup analysis of the research model under study. H6 corroborated that the buyer experience has significant negative effects on socially responsible buyers and the level of satisfaction. These findings align with behavioral reasoning theory and SIT, as past shopping experiences influence purchase decision, more so for green and/or eco-friendly products [90,91]. Therefore, with improved buyer experience, the socially responsible buyers increase, which can cause a decrease in their level of satisfaction [127]. Conversely, H7 showed that the shopping experience does not affect the effects generated among panic buyers and their level of satisfaction. Therefore, we interred that the experience with online shopping measured with the age of e-commerce users is not a factor determining the level of satisfaction [96]. According to motivational and behavioral theories, one of the impulses that encourages purchases in times with social, health, and economic problems is hysteria, terror, and fear due to the shortage of basic products for daily life [93-95].

Fourthly, we performed a multigroup analysis in connection with the moderating effect of the model under study. The results showed that the shopping experience only 
showed significant differences between online buyers with experience and limited experience regarding their level of satisfaction. With this, we verified that the online shopping experience is a moderately determining factor in evaluating the risk and the perceived benefits, which are indicators that affect customer satisfaction [73,128].

\subsection{Online Buying and Social Responsibility}

The study of the behavior of online buyers revealed that the attitudes and behaviors of consumers with these types of characteristics are constantly changing. Since the appearance of the Internet, it has emerged as the main trigger of technological and innovative development in marketing systems. The different forms of electronic commerce have widely penetrated the different market segments. For this study, business-to-consumer (B2C) is one of the markets where the use of new technologies and digital platforms has been a key factor in reaching online buyers [71,129]. Therefore, open purchases and/or online purchases are increasing; in short, physical or face-to-face commerce is suffering and experiencing new demands from different online consumers, changes that are moving companies toward online markets $[130,131]$. In short, despite the arrival of new platforms for e-commerce and/or open online shopping, websites continue to be one of the most widely used channels and preferred by online buyers [73,132]. Therefore, the design, security, privacy, and trust of websites are decisive in meeting the needs and satisfaction of online buyers $[52,67,132]$. There are different types of online buyers; in our study, we considered socially responsible buyers and panic buyers. In our findings, the behaviors of socially responsible buyers play a determining and influential role in the different physical and digital communities in which this type of responsible consumers manifests. The behaviors of the SBRs is among the topics that have aroused the most interest in recent decades in terms of corporate social responsibility (ethical, social, economic, and environmental aspects) $[75,133]$. For this reason, online businesses are placing more emphasis on the products and services that they offer for sale in their online markets; among the aspects that are considered are: product quality, supplier reputation, environmental certifications, moral and ethical business conduct (internal and external), and corporate image [134,135]. All these business practices are strengthened or weakened depending on the efficiency related to the ethical behavior of the business. In addition, the reputation and business image are conditioned and based on the efficiency of the advertising campaigns conducted by online businesses, and on the opinions, reviews, and recommendations from consumer to consumer on the different digital platforms [67]. All of this contributes to the experience, the purchase decision, and the benefits perceived by socially responsible consumers [136,137]. From the perspective of the theory of social identity, these manifestations of socially responsible buyers (social leaders in online markets) become factors that influence the ethical behaviors of the inhabitants of the communities $[45,138]$.

\subsection{Online Buying and Open Innovation}

Traditionally, companies of different sizes have been inclined toward the strategy of closed innovation; that is, they focus on the designs and improvements of their products and their processes only with the exchange of knowledge that occurs within the organization. However, the innovation paradigm has been evolving, and the postulates of Chesbrough [139] on open innovation explain that open systems to generate high-value services and products are decisive for consolidating commercial and financial competitiveness. Therefore, open innovation (OI) is defined as the use of intentional inputs and outputs of knowledge to accelerate the internal innovation of the company, resulting in its effect in the markets [65]. In addition, OI is generally classified as inbound and outbound: inbound innovation (inbound) is related to the flow of information and knowledge that is generated with collaboration agreements with external organizations $[38,140]$; outbound innovation is related to the activities and knowledge (products and services) generated and exploited by the company to make them available abroad [141,142]. That is why online businesses are adopting open innovation practices to develop and refine their business 
models. Among the innovative practices implemented by most businesses today is the use of technologies in the development of digital platforms for e-commerce activities to increase their sales, their customers, and their competitiveness in a growing market with high expectations. Open innovation practices are not sporadic or temporary actions; therefore, companies that are inclined toward this organizational strategy must assume it as part of their corporate philosophy and corporate culture [143]. In the context of e-commerce, consumer demands and technological changes require online companies to be at the forefront of technological innovation and continuously explore new innovation practices that exceed their borders. Therefore, a culture based on innovation allows the company to consolidate its image, its reputation, and trust in the online consumer. In addition, the basis of the organizational culture in open innovation and organizational learning provides the business leadership capacity that allows an organization to excel and be more competitive $[37,38]$. Conversely, Yun et al. [144], through their conceptual model, indicated that the culture for the dynamics of open innovation is the result of the interactions between entrepreneurship, internal entrepreneurship and entrepreneurship organizational. In addition, it is important for companies to have close external collaboration with other public and private entities to improve open innovation practices [145].

From the perspective and conception of e-commerce, many examples of open innovation practices are available, which are related to technological capacity, learning capacity, entrepreneurial-oriented capacity, and the capacity for market orientation $[29,37,146]$. Among the most prominent e-commerce platforms at the global level are Amazon, Airbnb, JD.com, Alibaba, eBay, and Rakuten, among others. These companies have the most successful e-commerce platforms in global markets and are leaders in online business models, acting as role models for other startups. For Alibaba, which is considered one of the most powerful e-commerce businesses in Asia and the world generates, around USD 40 billion annually in sales. In addition, this company has been the focus of study of many researchers, such as Yun et al. [147], who studied the evolution of this organization from its culture to its individual and collective practices of open innovation. They focused on three dimensions of Alibaba's open innovation dynamics: expansion of the business dynamic feedback loop, expansion of open innovation culture, and emergence and expansion of OI costs with the growth in open innovation. Through the dynamics of open innovation, Alibaba motivated the explosive emergence of e-commerce platforms. However, these dynamic open innovations also increased the complexity, that is, the costs, of open innovation. Therefore, the adoption of dynamic open innovation practices represents an organizational and financial challenge for companies that immerse themselves in this type of corporate innovation culture $[142,148]$.

New and current companies that decide to adopt and/or improve their business models related to e-commerce will have to practice a culture based on open innovation [149]. Schumpeterian's book Innovation Funnel Open to the New Combined Business Model Development Circle suggests that business leaders articulate technology with potential markets [150]. In addition, they suggest that the open innovation strategy be based on a business of innovation toward the customer, including internal and external factors that affect open innovation toward the user. They also proposed that companies that are about to adopt open innovation explore the innovation practices developed by more developed engineering departments with a global impact, such as Apple, Google, Tesla, etc. [150]. The authors showed how social entrepreneurs are adopting new open innovation practices in various sectors and in different regions around the world [150]. These social ventures usually have a major impact and the process of open innovation practices with completely disruptive ideas is widely manifested. Currently, the global capitalist economies focus on the open innovation economy (start-ups and small- and medium-sized enterprises (SMEs), closed innovation economy (big business), and social innovation economy (social enterprises and three independent sectors) [150]. Therefore, in these scenarios, the business models have to be alienated from the value enhancement focused on open innovation. Creativity and open innovation currently play a determining role for new ventures; especially when 
developing business ideas related to electronic commerce, most of these new businesses are based on agile methodologies such as the canvas method, design thinking, and scrum, amongst others [146,151,152]. Examples of open innovation in online businesses in a collaborative economy that are aligned with our findings from theoretical and empirical perspectives based on the TAM and the behavioral reasoning theory are the cased of Airbnb and Uber, who, through a model innovative and disruptive business, have achieved wider penetration into the online market than traditional businesses (hotels and other forms of physical accommodation and public transport) $[153,154]$. However, despite these business models focusing on providing a different service experience through usability facilities, the design of its digital platform and with constant interaction (synchronous and asynchronous) that is supported by new technologies like artificial intelligence and big data. These companies still face challenges in terms of the tax regulations of each country and the negative daily experiences that damage the quality of the service they provide, thereby damaging the reputation of the company $[155,156]$. Therefore, business models based on traditional approaches to linear innovation or the Schumpeterian linear perspective (Mark 1) are defined as creative destruction, which leads to the monopolistic practices of large companies with an increasingly numerous and highly innovative population of turbulent innovators. In addition to the Schumpeterian perspective (Mark 2), investment opportunities are disappearing, marking the end of capitalism in a population focused on innovation $[139,151,157]$. The new Schumpeterian perspective treats individual entrepreneurship, the monopolistic practices of large companies, and the socialist model not as linear steps but as a rotation or circular dynamic [36], with technology and the market economy being key factors or dynamic capabilities in the virtuous circle of the strategy for open innovation [142,158]. In general, large companies execute closed innovation practices through investment in research, development, and innovation $(\mathrm{R}+\mathrm{D}+\mathrm{I})$, but they also implement open innovation through mergers and acquisitions of smaller companies [36]. Regarding the economy based on market innovation in connection with technology, new businesses and SMEs interact more with communities through open and social innovations. In addition, SMEs are currently also focusing on investment in R+D+I, and new companies are being designed under more innovative business models with a social focus and from a stakeholder perspective [36,139].

\section{Conclusions}

Generally, we conclude that website security is a determining factor in generating satisfaction and trust in socially responsible buyers and panic buyers. The shopping experience plays a moderating role between socially responsible buyers and the level of satisfaction. Within the pandemic and Latin American contexts, our findings have theoretical and empirical implications in the field of socially responsible and panic buyers. From a theoretical perspective, the findings contribute to the literature on the technological adaptation model, showing that current consumers have a better experience and increased confidence in the use of digital platforms when conducting e-commerce transactions. The TAM and open innovation play a determining role in new online business models and the trust, security, and usability of websites being developed by companies. Therefore, this research shows that online shopping behavior and customer satisfaction are conditioned by website security and the design of new digital platforms in the development of e-commerce in an ever-increasing economy. More collaborative innovations in the e-commerce market represent a risk for new business models based on digital platforms; therefore, their success or failure depends on the acceptance, usability, value, and perceived risk of consumers [43]. The findings also contribute to the psychology literature by analyzing the socially responsible and panic behaviors of online shoppers; the study also provides an important contribution to the development of theories focused on business sciences such as marketing. Online consumers' shopping experiences are based on reasoned decisions, planned purchasing decisions, responsible purchasing decisions, social influence, and the adaptability of new technologies. In addition, this study provides important value through 
the website security construct as one of the factors that affect the satisfaction of online consumers. One of the online consumers that in recent times has had a greater focus of attention is the behavior and satisfaction of socially responsible buyers, this is mainly due to their ethical conduct and the impact generated by their social leadership. From the SIT, socially responsible buyers are promoters and leaders of communities that intervene in the purchase decision of other buyers; therefore, purchasing experiences, the level of innovation of digital platforms, and business reputation are the factors that determine their acceptance in developed and emerging economies. Consequently, the new online business models are trying to satisfy the needs of consumers and other stakeholders through achieving a sustainable business balance (social, economic, and environmental) [37,159]. Therefore, the empirical implications of the study translate into (1) online retail stores must rely on the permanent use of new and more efficient sales channels; (2) businesses based on e-commerce must increase the filters and security of websites and other online sales channels; (3) online consumers should more carefully reason decisions and purchase intentions; (4) socially responsible consumers are positive influencers of the majority of communities; (5) globalization, the economic situation, and the universal health situation will have a stronger influence on the online decisions and buying behaviors of consumers; and (6) businesses will have to incorporate innovative business models into their sales process and online marketing channels, through strategies and technological tools based on digital marketing, business intelligence and artificial intelligence.

Concerning our academic contributions, the findings are positive and encouraging, contributing to the literature on the e-commerce behaviors and attitudes of purchase intentions of individuals. Our work is incorporated into the literature on purchase intention and virtual business models, whose characteristics need to continue to be outlined, despite constituting a booming business model in recent years. Given the multiple areas of influence within any organization, from the academic field, the consequences of our research are important, outlining the relationships between interest groups and serving as guidance to the organization's management of adequate business processes.

The study is not free of limitations; therefore, in this section, we describe those that are the most significant. The first limitation is related to the design of the questionnaire, which was constructed based on adaptations from other studies. The second limitation is related to the analysis of the one-dimensional constructs, which, in future research, can be considered multidimensional constructs. The third limitation refers to the statistical technique used, which focused on the analysis of variance. In the future, analysis of covariance can be considered. Finally, another limitation is the sample and the location of the participants; in the future, participants from other regions and other countries may be considered to compare the results. This study has generated increased interest, which have been recently noticeable; however, it is important to continue with this type of study to monitor the phenomena related to the behavior and intentions of purchase of consumers online. Therefore, we suggest adding new variables that consider social, cultural, economic, and environmental aspects. For future work related to online consumer behavior, new variables or phenomena should be incorporated such as the measurement of service quality, product innovation, and corporate image. One of the main future lines of research emerging from this study from a Latin American context and under an emerging economy is analyzing online shopping behavior and the acceptance of new business models based on the design of digital platforms that have embraced open innovation and the sharing economy.

Author Contributions: L.E.V.-J., author of this work, and contributed to the research plan, the management of financial resources, and all sections of this manuscript; D.G.-V., author of this work, and contributed to the development of the literature, the conceptual framework, and the theoretical foundation of the model's hypotheses; E.A.R.-E., author of this work, and contributed to the review of the conclusions and the final review of the entire manuscript. All authors have read and agreed to the published version of the manuscript. 
Funding: This paper received funding for its development and publication by the Program for Strengthening Educational Quality (PFCE, 2020) of the Secretariat of Public Education of Mexico, and PROFAPI (2020-0022), ITSON Research Institutional Strengthening Program.

Informed Consent Statement: Informed consent was obtained from all subjects involved in the study.

Data Availability Statement: The data used in the study are available to other authors who require access to this material.

Conflicts of Interest: The authors declare no potential conflicts of interest with respect to the research, authorship, and publication of this article.

\section{References}

1. Downes, S.M. Evolutionary psychology is not the only productive evolutionary approach to understanding consumer behavior. J. Consum. Psychol. 2013, 23, 400-403. [CrossRef]

2. Sobol, K.; Cleveland, M.; Laroche, M. Globalization, national identity, biculturalism and consumer behavior: A longitudinal study of Dutch consumers. J. Bus. Res. 2018, 82, 340-353. [CrossRef]

3. Sahu, A.K.; Padhy, R.K.; Dhir, A. Envisioning the future of behavioral decision-making: A systematic literature review of behavioral reasoning theory. Australas. Mark. J. 2020, 28, 1-15. [CrossRef]

4. Sheppard, B.H.; Hartwick, J.; Warshaw, P.R. The Theory of Reasoned Action: A Meta-Analysis of Past Research with Recommendations for Modifications and Future Research. J. Consum. Res. 1988, 15, 325. [CrossRef]

5. Ajzen, I. The theory of planned behavior. Organ. Behav. Hum. Decis. Process. 1991, 50, 179-211. [CrossRef]

6. Singh, K.; Leong, S.M.; Tan, C.T.; Wong, K.C. A theory of reasoned action perspective of voting behavior: Model and empirical test. Psychol. Mark. 1995, 12,37-51. [CrossRef]

7. Westaby, J.D. Behavioral reasoning theory: Identifying new linkages underlying intentions and behavior. Organ. Behav. Hum. Decis. Process. 2005, 98, 97-120. [CrossRef]

8. Gupta, A.; Arora, N. Understanding determinants and barriers of mobile shopping adoption using behavioral reasoning theory. J. Retail. Consum. Serv. 2017, 36, 1-7. [CrossRef]

9. Kabanda, S.K.; Brown, I. E-commerce enablers and barriers in tanzanian small and medium enterprises. Electron. J. Inf. Syst. Dev. Ctries. 2015, 67, 1-24. [CrossRef]

10. Müller, J.M.; Buliga, O.; Voigt, K.-I. Fortune favors the prepared: How SMEs approach business model innovations in Industry 4.0. Technol. Forecast. Soc. Chang. 2018, 132, 2-17. [CrossRef]

11. Lee, Y.; Kozar, K.A. Designing usable online stores: A landscape preference perspective. Inf. Manag. 2009, 46, 31-41. [CrossRef]

12. Tandon, U.; Kiran, R.; Sah, A.N.; Kiran, R. The influence of website functionality, drivers and perceived risk on customer satisfaction in online shopping: An emerging economy case. Inf. Syst. e-Bus. Manag. 2018, 16, 57-91. [CrossRef]

13. Riegelsberger, J.; Sasse, M.A.; McCarthy, J.D. The mechanics of trust: A framework for research and design. Int. J. Hum. Comput. Stud. 2005, 62, 381-422. [CrossRef]

14. Liu, Y.; Li, H.; Hu, F. Website attributes in urging online impulse purchase: An empirical investigation on consumer perceptions. Decis. Support Syst. 2013, 55, 829-837. [CrossRef]

15. Kulviwat, S.; Bruner, G.C.; Kumar, A.; Nasco, S.A.; Clark, T. Toward a unified theory of consumer acceptance technology. Psychol. Mark. 2007, 24, 1059-1084. [CrossRef]

16. Yuen, K.F.; Wang, X.; Ma, F.; Li, K.X. The Psychological Causes of Panic Buying Following a Health Crisis. Int. J. Environ. Res. Public Health 2020, 17, 3513. [CrossRef]

17. Nicola, M.; Alsafi, Z.; Sohrabi, C.; Kerwan, A.; Al-Jabir, A.; Iosifidis, C.; Agha, M.; Agha, R. The socio-economic implications of the coronavirus pandemic (COVID-19): A review. Int. J. Surg. 2020, 78, 185-193. [CrossRef]

18. Arafat, S.M.Y.; Kar, S.K.; Menon, V.; Kaliamoorthy, C.; Mukherjee, S.; Alradie-Mohamed, A.; Sharma, P.; Marthoenis, M.; Kabir, R. Panic buying: An insight from the content analysis of media reports during COVID-19 pandemic. Neurol. Psychiatry Brain Res. 2020, 37, 100-103. [CrossRef]

19. Fernandes, N. Economic Effects of Coronavirus Outbreak (COVID-19) on the World Economy. SSRN Electron. J. 2020. [CrossRef]

20. Laato, S.; Islam, A.K.M.N.; Farooq, A.; Dhir, A. Unusual purchasing behavior during the early stages of the COVID-19 pandemic: The stimulus-organism-response approach. J. Retail. Consum. Serv. 2020, 57, 102224. [CrossRef]

21. Eggers, F. Masters of disasters? Challenges and opportunities for SMEs in times of crisis. J. Bus. Res. 2020, 116, 199-208. [CrossRef]

22. Lejoyeux, M.; Weinstein, A. Compulsive buying. Am. J. Drug Alcohol Abuse 2010, 36, 248-253. [CrossRef]

23. Kukar-Kinney, M.; Scheinbaum, A.C.; Schaefers, T. Compulsive buying in online daily deal settings: An investigation of motivations and contextual elements. J. Bus. Res. 2016, 69, 691-699. [CrossRef]

24. Akram, U.; Hui, P.; Kaleem Khan, M.; Tanveer, Y.; Mehmood, K.; Ahmad, W. How website quality affects online impulse buying: Moderating effects of sales promotion and credit card use. Asia Pacific J. Mark. Logist. 2018, 30, 235-256. [CrossRef]

25. Yuan, D.; Lin, Z.; Filieri, R.; Liu, R.; Zheng, M. Managing the product-harm crisis in the digital era: The role of consumer online brand community engagement. J. Bus. Res. 2020, 115, 38-47. [CrossRef]

26. West, J.; Salter, A.; Vanhaverbeke, W.; Chesbrough, H. Open innovation: The next decade. Res. Policy 2014, 43, 805-811. [CrossRef] 
27. Badawy, A.M. Open Innovation: The New Imperative for Creating and Profiting from Technology. J. Eng. Technol. Manag. 2004, 21, 241-244. [CrossRef]

28. Huang, H.-C. Technological innovation capability creation potential of open innovation: A cross-level analysis in the biotechnology industry. Technol. Anal. Strateg. Manag. 2011, 23, 49-63. [CrossRef]

29. Schiavi, G.S.; Behr, A.; Marcolin, C.B. Conceptualizing and qualifying disruptive business models. RAUSP Manag. J. 2019, 54, 269-286. [CrossRef]

30. Hsu, M.H.; Chang, C.M.; Chu, K.K.; Lee, Y.J. Determinants of repurchase intention in online group-buying: The perspectives of DeLone \& McLean is success model and trust. Comput. Human Behav. 2014, 36, 234-245. [CrossRef]

31. Pavlou, P.A. Consumer acceptance of electronic commerce: Integrating trust and risk with the technology acceptance model. Int. J. Electron. Commer. 2003, 7, 101-134. [CrossRef]

32. Perea, Y.; Monsuwé, T.; Dellaert, B.G.C.; De Ruyter, K. What drives consumers to shop online? A literature review. Int. J. Serv. Ind. Manag. 2004, 15, 102-121. [CrossRef]

33. WHO World Health Organization. Epidemiological Update Coronavirus Disease (COVID-19); WHO: Washington, DC, USA, 2020.

34. CEPAL Economic Commission for Latin America and the Caribbean. Sectors and Companies Facing COVID-19: Emergency and Reactivation; CEPAL: Santiago, Chile, 2020.

35. OECD Organisation for Economic Co-Operation and Development. Information and Communication Technology (ICT)—Internet Access-OECD Data. Available online: https:// data.oecd.org/ict/internet-access.htm (accessed on 29 December 2020).

36. Yun, J.H.J.; Won, D.K.; Park, K.B. Entrepreneurial cyclical dynamics of open innovation. J. Evol. Econ. 2018, 28, 1151-1174. [CrossRef]

37. Teece, D.J. Business models, business strategy and innovation. Long Range Plann. 2010, 43, 172-194. [CrossRef]

38. van de Vrande, V.; de Jong, J.P.J.; Vanhaverbeke, W.; de Rochemont, M. Open innovation in SMEs: Trends, motives and management challenges. Technovation 2009, 29, 423-437. [CrossRef]

39. Hassan, M.U.; Iqbal, Z.; Malik, M.; Ahmad, M.I. Exploring the role of technological developments and open innovation in the survival of SMEs: An empirical study of Pakistan. Int. J. Bus. Forecast. Mark. Intell. 2018, 4, 64. [CrossRef]

40. Ajzen, I. The theory of planned behaviour: Reactions and reflections. Psychol. Health 2011, 26, 1113-1127. [CrossRef] [PubMed]

41. Mustafa, S.Z.; Kar, A.K.; Janssen, M.F.W.H.A. Understanding the impact of digital service failure on users: Integrating Tan's failure and DeLone and McLean's success model. Int. J. Inf. Manag. 2020, 53. [CrossRef]

42. Csikszentmihalyi, M. The costs and benefits of consuming. J. Consum. Res. 2000, 27, 267-272. [CrossRef]

43. Talwar, S.; Talwar, M.; Kaur, P.; Dhir, A. Consumers' resistance to digital innovations: A systematic review and framework development. Australas. Mark. J. 2020. [CrossRef]

44. Hogg, M.A.; Ridgeway, C.L. Social Identity: Sociological and Social Psychological Perspectives. Soc. Psychol. Q. 2003, 66, 97-100.

45. Sidanius, J.; Pratto, F. Online Resources Social Identity Theory. J. Pers. Soc. Psychol. 2014, 67, 741-763.

46. Bartels, J.; Hoogendam, K. The role of social identity and attitudes toward sustainability brands in buying behaviors for organic products. J. Brand Manag. 2011, 18, 697-708. [CrossRef]

47. Fielding, K.S.; Hornsey, M.J. A Social Identity Analysis of Climate Change and Environmental Attitudes and Behaviors: Insights and Opportunities. Front. Psychol. 2016, 7, 121. [CrossRef] [PubMed]

48. DeLone, W.H.; McLean, E.R. Measuring e-commerce success: Applying the DeLone and McLean Information Systems Success Model. Int. J. Electron. Commer. 2004, 9, 31-47. [CrossRef]

49. Venkatesh, V.; Davis, F.D. A theoretical extension of the technology acceptance model: Four longitudinal field studies. Manag. Sci. 2000, 46, 186-204. [CrossRef]

50. Lee, Y.; Kozar, K.A.; Larsen, K.R.T.; Lee, Y.; Kozar, K.A.; Lee, Y.; Kozar, K.A.; Larsen, K.R.T. The Technology Acceptance Model: Past, Present, and Future. Commun. Assoc. Inf. Syst. 2003, 12, 752-780. [CrossRef]

51. Al-Qirim, N. The adoption of eCommerce communications and applications technologies in small businesses in New Zealand. Electron. Commer. Res. Appl. 2007, 6, 462-473. [CrossRef]

52. Bt Mohd, N.A.; Zaaba, Z.F. A review of usability and security evaluation model of E-commerce website. In Proceedings of the Procedia Computer Science; Elsevier B.V.: Amsterdam, The Netherlands, 2019; Volume 161, pp. 1199-1205.

53. Blut, M. E-Service Quality: Development of a Hierarchical Model. J. Retail. 2016, 92, 500-517. [CrossRef]

54. Rita, P.; Oliveira, T.; Farisa, A. The impact of e-service quality and customer satisfaction on customer behavior in online shopping. Heliyon 2019, 5, e02690. [CrossRef]

55. Hasan, L.; Morris, A.; Probets, S. A comparison of usability evaluation methods for evaluating e-commerce websites. Behav. Inf. Technol. 2012, 31, 707-737. [CrossRef]

56. Limbu, Y.B.; Wolf, M.; Lunsford, D. Perceived ethics of online retailers and consumer behavioral intentions: The mediating roles of trust and attitude. J. Res. Interact. Mark. 2012, 6, 133-154. [CrossRef]

57. Kim, J.; Lennon, S.J. Effects of reputation and website quality on online consumers' emotion, perceived risk and purchase intention: Based on the stimulus-organism-response model. J. Res. Interact. Mark. 2013, 7, 33-56. [CrossRef]

58. Odusanya, K.; Aluko, O.; Lal, B. Building Consumers' Trust in Electronic Retail Platforms in the Sub-Saharan Context: An exploratory study on Drivers and Impact on Continuance Intention. Inf. Syst. Front. 2020, 1-15. [CrossRef]

59. Pernot, D. Internet shopping for Everyday Consumer Goods: An examination of the purchasing and travel practices of click and pickup outlet customers. Res. Transp. Econ. 2020, 100817. [CrossRef] 
60. Hurlburt, G.F. Web 2.0 Social Media: A Commercialization Conundrum. IT Prof. 2012, 14, 6-8. [CrossRef]

61. Wang, Y.; Xiang, D.; Yang, Z.Y.; Ma, S.S. Unraveling customer sustainable consumption behaviors in sharing economy: A socioeconomic approach based on social exchange theory. J. Clean. Prod. 2019, 208, 869-879. [CrossRef]

62. Oláh, J.; Kitukutha, N.; Haddad, H.; Pakurár, M.; Máté, D.; Popp, J. Achieving Sustainable E-Commerce in Environmental, Social and Economic Dimensions by Taking Possible Trade-Offs. Sustainability 2018, 11, 89. [CrossRef]

63. Rovetta, A.; Bhagavathula, A.S. COVID-19-Related Web Search Behaviors and Infodemic Attitudes in Italy: Infodemiological Study. JMIR Public Heal. Surveill. 2020, 6, e19374. [CrossRef]

64. Naeem, M. Do social media platforms develop consumer panic buying during the fear of Covid-19 pandemic. J. Retail. Consum. Serv. 2021, 58, 102226. [CrossRef]

65. Gassmann, O.; Enkel, E.; Chesbrough, H. The future of open innovation. R D Manag. 2010, 40, 213-221. [CrossRef]

66. Chen, J.V.; Yen, D.C.; Widjaja, A.E.; Chen, J.V.; Pornpriphet, W. E-commerce web site loyalty: A cross cultural comparison. Inf. Syst. Front. 2014. [CrossRef]

67. Casaló, L.; Flavián, C.; Guinalíu, M. The role of perceived usability, reputation, satisfaction and consumer familiarity on the website loyalty formation process. Comput. Human Behav. 2008, 24, 325-345. [CrossRef]

68. Flavián, C.; Gurrea, R.; Orús, C. Feeling Confident and Smart with Webrooming: Understanding the Consumer's Path to Satisfaction. J. Interact. Mark. 2019, 47, 1-15. [CrossRef]

69. Cheah, J.H.; Lim, X.J.; Ting, H.; Liu, Y.; Quach, S. Are privacy concerns still relevant? Revisiting consumer behaviour in omnichannel retailing. J. Retail. Consum. Serv. 2020, 102242. [CrossRef]

70. Chi, T. Mobile Commerce Website Success: Antecedents of Consumer Satisfaction and Purchase Intention. Artic. J. Internet Commer. 2018, 17, 189-215. [CrossRef]

71. Zhu, D.H.; Deng, Z.Z.; Chang, Y.P. Understanding the influence of submission devices on online consumer reviews:A comparison between smartphones and PCs. J. Retail. Consum. Serv. 2020, 54, 102028. [CrossRef]

72. Sia, W.C.; Tiu, R.A.; Tangsoc, J.C. A user experience evaluation for wendy's online delivery website geared towards improving customer experience. In Proceedings of the 2017 IEEE International Conference on Industrial Engineering and Engineering Management (IEEM), Singapore, 10-13 December 2017; pp. 1853-1857.

73. Chang, S.H.; Chih, W.H.; Liou, D.K.; Yang, Y.T. The mediation of cognitive attitude for online shopping. Inf. Technol. People 2016, 29, 618-646. [CrossRef]

74. Ingenbleek, P.T.M.; Meulenberg, M.T.G.; Van Trijp, H.C.M. Buyer social responsibility: A general concept and its implications for marketing management. J. Mark. Manag. 2015, 31, 1428-1448. [CrossRef]

75. Kim, M.; Yin, X.; Lee, G. The effect of CSR on corporate image, customer citizenship behaviors, and customers' long-term relationship orientation. Int. J. Hosp. Manag. 2020, 88, 102520. [CrossRef]

76. Swaen, V.; Chumpitaz, R.C. Impact of Corporate Social Responsibility on Consumer Trust. Rech. Appl. Mark. Engl. Ed. 2008, 23, 7-34. [CrossRef]

77. Becchetti, L.; Corrado, G.; Pelligra, V.; Rossetti, F. Satisfaction and preferences in a legality social dilemma: Does corporate social responsibility impact consumers' behaviour? J. Policy Model. 2020, 42, 483-502. [CrossRef]

78. He, H.; Harris, L. The impact of Covid-19 pandemic on corporate social responsibility and marketing philosophy. J. Bus. Res. 2020, 116, 176-182. [CrossRef] [PubMed]

79. Panda, T.K.; Kumar, A.; Jakhar, S.; Luthra, S.; Garza-Reyes, J.A.; Kazancoglu, I.; Nayak, S.S. Social and environmental sustainability model on consumers' altruism, green purchase intention, green brand loyalty and evangelism. J. Clean. Prod. 2020, $243,118575$. [CrossRef]

80. Fazal-e-Hasan, S.M.; Ahmadi, H.; Mortimer, G.; Grimmer, M.; Kelly, L. Examining the role of consumer hope in explaining the impact of perceived brand value on customer-brand relationship outcomes in an online retailing environment. J. Retail. Consum. Serv. 2018, 41, 101-111. [CrossRef]

81. Kim, J.; Park, T. How corporate social responsibility (CSR) saves a company: The role of gratitude in buffering vindictive consumer behavior from product failures. J. Bus. Res. 2020, 117, 461-472. [CrossRef]

82. Rahimah, A.; Khalil, S.; Dang, H.P.; Ming-Sung Cheng, J. The terror of death and consumers' sustainability attitudes. J. Retail. Consum. Serv. 2020, 57, 102196. [CrossRef]

83. Islam, D.T.; Pitafi, D.H.; Wang, D.Y.; Aryaa, D.V.; Mubarik, D.S.; Akhater, D.N.; Xiaobei, D.L. Panic Buying in the COVID-19 Pandemic: A Multi-Country Examination. J. Retail. Consum. Serv. 2020, 57, 2-55. [CrossRef]

84. Pantano, E.; Pizzi, G.; Scarpi, D.; Dennis, C. Competing during a pandemic? Retailers' ups and downs during the COVID-19 outbreak. J. Bus. Res. 2020, 116, 209-213. [CrossRef]

85. Saini, C. Difficulty in Transition: Study on Hindrances in Online Shopping for Potential Shoppers. Rev. Int. Mark. Online 2020, 10, 17-29. [CrossRef]

86. Harris, P.; Dall'Olmo Riley, F.; Hand, C. Multichannel shopping: The effect of decision making style on shopper journey configuration and satisfaction. J. Retail. Consum. Serv. 2021, 58, 102286. [CrossRef]

87. Kirk, C.P.; Rifkin, L.S. I'll trade you diamonds for toilet paper: Consumer reacting, coping and adapting behaviors in the COVID-19 pandemic. J. Bus. Res. 2020, 117, 124-131. [CrossRef] [PubMed]

88. Constantinides, E. Influencing the online consumer's behavior: The Web experience Efthymios Constantinides. Internet Res. 2004, 14, 111-126. [CrossRef] 
89. Yang, Y.; Gong, Y.; Land, L.P.W.; Chesney, T. Understanding the effects of physical experience and information integration on consumer use of online to offline commerce. Int. J. Inf. Manag. 2020, 51, 102046. [CrossRef]

90. Javed, M.K.; Wu, M. Effects of online retailer after delivery services on repurchase intention: An empirical analysis of customers' past experience and future confidence with the retailer. J. Retail. Consum. Serv. 2020, 54, 101942. [CrossRef]

91. Robina-Ramírez, R.; Chamorro-Mera, A.; Moreno-Luna, L. Organic and online attributes for buying and selling agricultural products in the e-marketplace in Spain. Electron. Commer. Res. Appl. 2020, 42, 100992. [CrossRef]

92. Tsao, Y.C.; Thanh, V.V.; Lu, J.C.; Wei, H.H. A risk-sharing-based resilient renewable energy supply network model under the COVID-19 pandemic. Sustain. Prod. Consum. 2021, 25, 484-498. [CrossRef]

93. Vancic, A.; Pärson, G.F.A. Changed Buying Behavior in the COVID-19 pandemic: The influence of Price Sensitivity and Perceived Quality; Kristianstad University: Kristianstad, Sweden, 2020.

94. Hao, N.; Wang, H.H.; Zhou, Q. The impact of online grocery shopping on stockpile behavior in Covid-19. China Agric. Econ. Rev. 2020, 12, 459-470. [CrossRef]

95. Duygun, A.; Üniversitesi, G.; Şen, E. Evaluation of Consumer Purchasing Behaviors in the COVID-19 Pandemic Period in the Context of Maslow's Hierarchy of Needs. PazarlamaTeorisi ve Uygulamaları Dergisi 2020, 6, 45-68.

96. Pappas, I.O.; Pateli, A.G.; Giannakos, M.N.; Chrissikopoulos, V. Moderating effects of online shopping experience on customer satisfaction and repurchase intentions Satisfaction and repurchase intentions 187. Int. J. Retail Distrib. Manag. 2014, 42, 187-204. [CrossRef]

97. Khalifa, M.; Liu, V. Online consumer retention: Contingent effects of online shopping habit and online shopping experience. Eur. J. Inf. Syst. 2007, 16, 780-792. [CrossRef]

98. INEGI National Institute of Geography, Informatics and Statistics. Occupation and Employment Indicators, Unemployment Rate, December 2018 DECEMBER 2018 Seasonally Adjusted and Trend-Cycle Series (Percentage of the EAP); INEG: Aguascalientes, Mexico, 2019.

99. Mexican Internet Association. Movilidad en el Usuario de Internet Mexicano; AMIPCI: Mexico City, Mexico, 2019.

100. Diamantopoulos, A.; Siguaw, J.A. Formative versus reflective indicators in organizational measure development: A comparison and empirical illustration. Br. J. Manag. 2006, 17, 263-282. [CrossRef]

101. Devon, H.A.; Block, M.E.; Moyle-Wright, P.; Ernst, D.M.; Hayden, S.J.; Lazzara, D.J.; Savoy, S.M.; Kostas-Polston, E. A psychometric toolbox for testing validity and reliability. J. Nurs. Scholarsh. 2007, 39, 155-164. [CrossRef] [PubMed]

102. Diamantopoulos, A.; Reynolds, N.; Schlegelmilch, B. Pretesting in Questionnaire Design: The Impact of Respondent Characteristics on Error Detection. Mark. Res. Soc. J. 1994, 36, 1-15. [CrossRef]

103. Malhotra, N.K.; Kim, S.S.; Patil, A. Common Method Variance in IS Research: A Comparison of Alternative Approaches and a Reanalysis of Past Research. Manag. Sci. 2006, 52, 1865-1883. [CrossRef]

104. Podsakoff, P.M.; MacKenzie, S.B.; Lee, J.; Podsakoff, N.P. Common Method Bias in Behavioral Research: A Critical Review of the Literature and Recommended Remedies. J. Appl. Psychol. 2003, 885. [CrossRef]

105. Van Riel, A.C.R.; Henseler, J.; Kemény, I.; Sasovova, Z. Estimating hierarchical constructs using consistent partial least squares. Ind. Manag. Data Syst. 2017, 117, 459-477. [CrossRef]

106. Lee, M.K.O.; Turban, E. A trust model for consumer internet shopping. Int. J. Electron. Commer. 2001, 6, 75-91. [CrossRef]

107. Diamantopoulos, A.; Schlegelmilch, B.B.; Sinkovics, R.R.; Bohlen, G.M. Can socio-demographics still play a role in profiling green consumers? A review of the evidence and an empirical investigation. J. Bus. Res. 2003, 56, 465-480. [CrossRef]

108. Barbarossa, C.; De Pelsmacker, P. Positive and Negative Antecedents of Purchasing Eco-friendly Products: A Comparison between Green and Non-green Consumers. J. Bus. Ethics 2016, 134, 229-247. [CrossRef]

109. Buerke, A.; Straatmann, T.; Lin-Hi, N.; Müller, K. Consumer awareness and sustainability-focused value orientation as motivating factors of responsible consumer behavior. Rev. Manag. Sci. 2017, 11, 959-991. [CrossRef]

110. Zeithami, V.; Berry, L.L.; Parasuraman, A. The behavioral consequences of service quality. J. Mark. 1996, 60, 31-46. [CrossRef]

111. Hausman, A.V.; Siekpe, J.S. The effect of web interface features on consumer online purchase intentions. J. Bus. Res. 2009, 62, 5-13. [CrossRef]

112. Fornell, C.; Larcker, D.F. Evaluating Structural Equation Models with Unobservable Variables and Measurement Error. J. Mark. Res. 1981, 18, 39-50. [CrossRef]

113. Henseler, J.; Ringle, C.M.; Sarstedt, M. A new criterion for assessing discriminant validity in variance-based structural equation modeling. J. Acad. Mark. Sci. 2015, 43, 115-135. [CrossRef]

114. Henseler, J. Bridging Design and Behavioral Research with Variance-Based Structural Equation Modeling. J. Advert. 2017, 46, 178-192. [CrossRef]

115. Gold, A.H.; Malhotra, A.; Segars, A.H. Knowledge Management: An Organizational Capabilities Perspective. J. Manag. Inf. Syst. 2001, 18, 185-214. [CrossRef]

116. Hair, J.F., Jr.; Sarstedt, M.; Ringle, C.M.; Gudergan, S.P. Advanced Issues in Partial Least Squares Structural Equation Modeling; SAGE: Thousand Oaks, CA, USA, 2017; EISBN 1483377385; EISBN-13 9781483377384.

117. Sanchez-Franco, M.J.; Cepeda-Carrion, G.; Roldán, J.L. Understanding relationship quality in hospitality services. Internet Res. 2019, 29, 478-503. [CrossRef]

118. Henseler, J.; Ringle, C.M.; Sinkovics, R.R. The use of partial least squares path modeling in international marketing. In New Challenges to International Marketing; Emerald Group Publishing: Bradford, UK, 2009; pp. 277-319. 
119. Hair, J.F.; Sarstedt, M.; Hopkins, L.; Kuppelwieser, V.G. Partial least squares structural equation modeling (PLS-SEM): An emerging tool in business research. Eur. Bus. Rev. 2014, 26, 106-121. [CrossRef]

120. Chin, W.W.; Dibbern, J. Handbook of Partial Least Squares; Springer Science \& Business Media: Berlin, Germany, 2010; ISBN 978-3-540-32825-4.

121. Chin, W.W. The partial least squares approach to structural equation modeling. In Modern Methods for Business Research; Marcoulides, G.A., Ed.; Lawrence Erlbaum: New Jersey, NJ, USA, 1998; pp. 295-336.

122. Hu, L.; Bentler, P.M. Cutoff criteria for fit indexes in covariance structure analysis: Conventional criteria versus new alternatives. Struct. Equ. Model. A Multidiscip. J. 1999, 6, 1-55. [CrossRef]

123. Henseler, J.; Hubona, G.; Ray, P.A. Using PLS path modeling in new technology research: Updated guidelines. Ind. Manag. Data Syst. 2016, 116, 2-20. [CrossRef]

124. Hair, J.F.; Risher, J.J.; Sarstedt, M.; Ringle, C.M. When to use and how to report the results of PLS-SEM. Eur. Bus. Rev. 2019, 31, 2-24. [CrossRef]

125. Becker, J.-M.; Ringle, C.M.; Sarstedt, M. Estimating Moderating Effects in PLS-SEM and PLSc-SEM: Interaction Term Generation*Data Treatment SmartPLS 3.x View project Application of PLS-SEM in Banking \& Finance View project. J. Appl. Struct. Equ. Model. 2018. [CrossRef]

126. Henseler, J.; Ringle, C.M.; Sarstedt, M. Testing measurement invariance of composites using partial least squares. Int. Mark. Rev. 2016, 33, 405-431. [CrossRef]

127. Tandon, A.; Dhir, A.; Kaur, P.; Kushwah, S.; Salo, J. Why do people buy organic food? The moderating role of environmental concerns and trust. J. Retail. Consum. Serv. 2020, 57, 102247. [CrossRef]

128. Walls, A.R.; Okumus, F.; (Raymond) Wang, Y.; Kwun, D.J.-W. An epistemological view of consumer experiences. Int. J. Hosp. Manag. 2011, 30, 10-21. [CrossRef]

129. Niranjanamurthy, M.; Kavyashree, N.; Jagannath, S.; Chahar, D. Analysis of E-Commerce and M-Commerce: Advantages, Limitations and Security Issues. Int. J. Adv. Res. Comput. Commun. Eng. 2013, 2, 2360-2370.

130. Chiou, J.S.; Chou, S.Y.; Shen, G.C.C. Consumer choice of multichannel shopping: The effects of relationship investment and online store preference. Internet Res. 2017, 27, 2-20. [CrossRef]

131. Ahmad, S.Z.; Abu Bakar, A.R.; Faziharudean, T.M.; Mohamad Zaki, K.A. An Empirical Study of Factors Affecting e-Commerce Adoption among Small- and Medium-Sized Enterprises in a Developing Country: Evidence from Malaysia. Inf. Technol. Dev. 2015, 21, 555-572. [CrossRef]

132. Cyr, D.; Bonanni, C.; Bowes, J.; Ilsever, J. Beyond Trust: Website Design Preferences across Cultures Beyond Trust: Website Design Preferences across Cultures. JGIM 2005, 13, 25-54. [CrossRef]

133. Talwar, S.; Jabeen, F.; Tandon, A.; Sakashita, M.; Dhir, A. What drives willingness to purchase and stated buying behavior toward organic food? A Stimulus-Organism-Behavior-Consequence (SOBC) perspective. J. Clean. Prod. 2021, 125882. [CrossRef]

134. Cavaleri, S.; Shabana, K. Rethinking sustainability strategies. J. Strateg. Manag. 2018, 11, 2-17. [CrossRef]

135. Lau, A.; Lee, S.; Jung, S. The Role of the Institutional Environment in the Relationship between CSR and Operational Performance: An Empirical Study in Korean Manufacturing Industries. Sustainability 2018, 10, 834. [CrossRef]

136. Abdul-Muhmin, A.G. Explaining consumers' willingness to be environmentally friendly. Int. J. Consum. Stud. 2007, 31, 237-247. [CrossRef]

137. Sudbury-Riley, L.; Kohlbacher, F. Ethically minded consumer behavior: Scale review, development, and validation. J. Bus. Res. 2016, 69, 2697-2710. [CrossRef]

138. Davis, J.L.; Love, T.P.; Fares, P. Collective Social Identity: Synthesizing Identity Theory and Social Identity Theory Using Digital Data. Soc. Psychol. Q. 2019, 82, 254-273. [CrossRef]

139. Chesbrough, H.W. Open Innovation: The New Imperative for Creating and Profiting from Technology; Harvard Business School Press: Boston, MA, USA, 2006; ISBN 9781422102831.

140. Becker, B.A.; Eube, C. Open innovation concept: Integrating universities and business in digital age. Eube J. Open Innov. Technol. Mark. Complex. 2018, 4, 12. [CrossRef]

141. Leitão, J.; Pereira, D.; de Brito, S. Inbound and Outbound Practices of Open Innovation and Eco-Innovation: Contrasting Bioeconomy and Non-Bioeconomy Firms. J. Open Innov. Technol. Mark. Complex 2020, 6, 145. [CrossRef]

142. Tucci, C.L.; Chesbrough, H.; Piller, F.; West, J. When do firms undertake open, collaborative activities? Introduction to the special section on open innovation and open business models. Ind. Corp. Chang. 2016, 25, 283-288. [CrossRef]

143. Podmetina, D.; Soderquist, K.E.; Petraite, M.; Teplov, R. Developing a competency model for open innovation: From the individual to the organisational level. Manag. Decis. 2018. [CrossRef]

144. Yun, J.H.J.; Zhao, X.; Jung, K.H.; Yigitcanlar, T. The culture for open innovation dynamics. Sustainability 2020, 12, 5076. [CrossRef]

145. Jugend, D.; Fiorini, P.D.C.; Armellini, F.; Ferrari, A.G. Public support for innovation: A systematic review of the literature and implications for open innovation. Technol. Forecast. Soc. Chang. 2020, 156, 119985. [CrossRef]

146. Teece, D.J. Dynamic capabilities and entrepreneurial management in large organizations: Toward a theory of the (entrepreneurial) firm. Eur. Econ. Rev. 2016, 86, 202-216. [CrossRef]

147. Yun, J.J.; Zhao, X.; Park, K. Sustainability Condition of Open Innovation: Dynamic Growth of Alibaba from SME to Large Enterprise. Sustainability 2020, 12, 4379. [CrossRef] 
148. Oduro, S. Exploring the barriers to SMEs' open innovation adoption in Ghana: A mixed research approach. Int. J. Innov. Sci. 2020. [CrossRef]

149. Haaker, T.; Ly, P.T.M.; Nguyen-Thanh, N.; Nguyen, H.T.H. Business model innovation through the application of the Internet-ofThings: A comparative analysis. J. Bus. Res. 2021, 126, 126-136. [CrossRef]

150. Yun, J.J. Business Model Design Compass; Management for Professionals; Springer: Singapore, 2017; ISBN 978-981-10-4126-6.

151. Mishra, C.S.; Zachary, R.K. The Theory of Entrepreneurship: Creating and Sustaining Entrepreneurial Value; Springer International Publishing: Berlin/Heidelberg, Germany, 2014; ISBN 9781137371461.

152. Shahab, Y.; Chengang, Y.; Arbizu, A.D.; Haider, M.J. Entrepreneurial self-efficacy and intention: Do entrepreneurial creativity and education matter? Int. J. Entrep. Behav. Res. 2019, 25, 259-280. [CrossRef]

153. Wirtz, J.; So, K.K.F.; Mody, M.A.; Liu, S.Q.; Chun, H.E.H. Platforms in the peer-to-peer sharing economy. J. Serv. Manag. 2019, 30, 452-483. [CrossRef]

154. Altman, E.J.; Tushman, M.L. Platforms, open/user innovation, and ecosystems: A strategic leadership perspective. Adv. Strateg. Manag. 2017, 37, 177-207. [CrossRef]

155. Sthapit, E.; Björk, P.; Jiménez Barreto, J. Negative memorable experience: North American and British Airbnb guests' perspectives. Tour. Rev. 2020. [CrossRef]

156. Guttentag, D. Progress on Airbnb: A literature review. J. Hosp. Tour. Technol. 2019, 10, 233-263. [CrossRef]

157. Schumpeter, J. The creative response in economic history. J. Econ. Hist. 1947, 7, 149-159. [CrossRef]

158. Teece, D.J. Explicating dynamic capabilities: The nature and microfoundations of (sustainable) enterprise performance. Strateg. Manag. J. 2007, 28, 1319-1350. [CrossRef]

159. Nosratabadi, S.; Mosavi, A.; Shamshirband, S.; Kazimieras Zavadskas, E.; Rakotonirainy, A.; Chau, K.W. Sustainable Business Models: A Review. Sustainability 2019, 11, 1663. [CrossRef] 